\title{
Phosphomannans and Other Components of Flocculent and Non-Flocculent Walls of Saccharomyces cerevisiae
}

\author{
BY P. J. MILL \\ Miles Laboratories Ltd., Stoke Court, Stoke Poges, Buckinghamshire
}

(Received 16 November 1965)

\begin{abstract}
SUMMARY
Preparations of flocculent and of non-flocculent cell walls were obtained from flocculent and non-flocculent cells of a strain of Saccharomyces cerevisiae. Flocculent walls contained $46 \%$ glucan, $43 \%$ mannan, $0 \cdot 4 \% \mathrm{P}$, $\mathbf{1} \cdot \mathbf{1} \%$ hexosamine, $\mathbf{0} \cdot \mathbf{7 9} \%$ non-hexosamine $\mathrm{N}$; non-flocculent walls contained $47 \%$ glucan, $44 \%$ mannan, $0.3 \% \mathrm{P}, \mathbf{1 . 2} \%$ hexosamine and $0.98 \%$ non-hexosamine $\mathbf{N}$.

Mannose-6-phosphate was identified as the principal phosphorus compound present. The mannose residue formed part of the cell-wall mannan and the phosphate was also linked by a second, labile, ester bond to an unidentified site. The degree of phosphorylation of the mannan varied from 1 phosphate to 19 mannose residues in non-flocculent cells to 1 phosphate to 13 residues in flocculent cells.
\end{abstract}

\section{INTRODUCTION}

The principal components of the cell walls of $\boldsymbol{S a c c h a r o m y c e s ~ c e r e v i s i a e ~ a r e ~ a ~ g l u c a n ~}$ and a mannan. Northcote \& Horne (1952) found that cell walls isolated from bakers' yeast contained $29 \%$ glucan, $31 \%$ mannan, and $13 \%$ protein. Roelofsen (1953) reported $34 \%, 34 \%$ and $6 \%$ for the same components. Masschelein and his colleagues (Masschelein \& Devreux, 1957 ; Masschelein, 1959 ; Masschelein, JeunehommeRamos, Castiau \& Devreux, 1963) found that with Saccharomyces carlsbergensis non-flocculent organisms contained a higher proportion of mannan than flocculent organisms.

In considering changes in the cell wall which might be manifested as changes in the potential flocculence of the cell, it seemed that a comparison of the compositions of walls isolated from flocculent and non-flocculent organisms of the same strain of yeast might be useful. In fact, little difference was found in the polysaccharide composition of such preparations. However, there was a difference in the content of organic phosphate in flocculent and non-flocculent organisms. This phosphate was found to be present as an ester of some of the hydroxyl groups at position 6 of mannose residues in the mannan. The degree of phosphorylation of the mannan was greater in flocculent than non-flocculent organisms.

\section{METHODS}

The strain of Saccharomyces cerevisiae and the glucose + yeast extract + salts + ammonia medium were as described by Mill (1964). Yeast was grown in 6 l. medium in $10 \mathrm{l}$. glass bottles which were fitted with bungs carrying air inlets and outlets. 
A brisk stream of filtered air was passed into the medium through a coarse sintered glass disc during the entire incubation period. Inocula were as described by Mill (1964). Non-flocculent organisms were obtained by harvesting at $20 \mathrm{hr}$ and flocculent organisms at $48 \mathrm{hr}$ after inoculation and the harvested organisms were at once washed in $1 \%(\mathrm{w} / \mathrm{v}) \mathrm{NaCl}$.

Preparation of cell walls. Organisms were washed in a $\mathrm{pH} \mathrm{7.0}$ buffer $(3.57 \mathrm{~g}$. $\mathrm{KH}_{2} \mathrm{PO}_{4}, 16 \cdot 35 \mathrm{~g}$. $\mathrm{Na}_{2} \mathrm{HPO}_{4}, 100$ g. mannitol, 1 g. sodium dodecyl sulphate made up to $1 \mathrm{l}$. in water) and were then disrupted in a Braun cell homogenizer (B. Braun, Melsungen, Germany). Five g. washed yeast, $45 \mathrm{~g}$. glass beads $(0.5 \mathrm{~mm}$. diam.), $4 \mathrm{ml}$. buffer and $0.1 \mathrm{ml}$. octanol were shaken together for $2 \mathrm{~min}$. The container was cooled with a stream of liquid $\mathrm{CO}_{2}$ from a cylinder so that the temperature of the homogenate did not rise above about $15^{\circ}$. The cellular material was decanted from the glass beads and these were washed with a little buffer and the washings added to the homogenate. Microscopic observation showed that the preparation contained cell walls, a very few unbroken cells and a quantity of small cellular debris, particularly very small, highly refractile particles which stained intensely with crystal violet. It was found that if the mixture of cell walls and debris was shaken with ether and buffer and the resulting suspension was centrifuged at a suitable speed and temperature, then the bulk of the cell walls collected on the bottom of the centrifuge tube, whereas unbroken cells and cellular debris tended to collect at the interface between the ether and buffer. This finding was used in the purification scheme for the cell walls which is outlined in Table 1.

Table 1. Method of purification of cell walls after disruption of organisms in homogenizer

Step 1

Mixture of walls and debris after homogenization, centrifuged at $250 \mathrm{~g}, 5^{\circ}, 15 \mathrm{~min}$.

Step 2

Residue suspended in buffer and centrifuged as above. This step repeated four times more.

Step 3

Residue suspended in equal volumes of buffer and ether and shaken vigorously, $10 \mathrm{~min}$. Mixture centrifuged at $2200 \mathrm{~g}, 2^{\circ}, 20 \mathrm{~min}$. This step repeated four times more.

Step 4

Residue shaken with glass beads in homogenizer as in original disruption, and walls collected as in step 1 .

Step 5

Steps 2 and 3 repeated alternately until cell walls appeared free of contaminants.

The quality of the preparation was judged throughout under the microscope by using both phase-contrast illumination and transmitted light after staining with crystal violet. Satisfactory preparations did not contain any unbroken organisms and showed only an occasional small refractile particle as a contaminant. Finally the walls were washed three times with $1 \%(\mathrm{w} / \mathrm{v}) \mathrm{NaCl}$ and three times with distilled water and were stored at $4^{\circ}$ in $0.01 \%$ thiomersalate solution. Before use the thiomersalate was removed by washing the walls in water.

Dry weights. Dry weights were determined by heating aqueous suspensions of walls at $95 \%$ in tared vessels until an approximately constant weight was obtained. All references to masses of cell walls refer to equivalent dry weights. 
Preparation of mannan. The method of isolating mannan from whole yeast was based on that of Haworth, Hirst \& Isherwood (1937), somewhat modified in the light of experience gained with the material obtained from our strain of yeast. One hundred g. yeast (wet wt.) was washed three times in distilled water and suspended in $200 \mathrm{ml} .6 \% \mathrm{NaOH}$. The suspension was heated at $100^{\circ}$ for $1 \mathrm{hr}$, cooled and brought to $\mathrm{pH} 8$ with concentrated acetic acid. The mixture was centrifuged and Fehling's solution was added drop by drop to the supernatant until no further precipitate was produced. After $30 \mathrm{~min}$. the gummy residue was collected and suspended in $40 \mathrm{ml}$. water. Two $\mathrm{ml}$. conc. $\mathrm{HCl}$ were added, the mixture was centrifuged at $2^{\circ}$ and the supernatant decanted into $200 \mathrm{ml}$. ethanol. The precipitate was collected, dissolved in $40 \mathrm{ml}$. water and brought to $\mathrm{pH} 7$ with $10 \%$ (w/v) $\mathrm{KOH}$. One $\mathrm{ml} .1 \% \mathrm{CaCl}_{2}$ solution was added and the mixture was poured into $250 \mathrm{ml}$. of ethanol. The precipitate was dissolved in $40 \mathrm{ml}$. water and dialysed for a total of $24 \mathrm{hr}$ against two 2 l. volumes $0 \cdot 1 \% \mathrm{CaCl}_{2}$ solution. The dialysed solution was poured into $200 \mathrm{ml}$. ethanol. The residue was dissolved in $40 \mathrm{ml} .0 \cdot 1 \% \mathrm{CaCl}_{2}$ and reprecipitated in $200 \mathrm{ml}$. ethanol. Finally it was washed twice each with $80 \%$ ethanol, $100 \%$ ethanol, and ether, and dried in a vacuum desiccator.

Glucose. Glucose was determined manometrically with glucose oxidase (Kaplan, 1957).

Total reducing sugar. The sugar content of hydrolysates of cell walls was determined by an alkaline copper-arsenomolybdate technique (Nelson, 1944).

Carbohydrate content of walls. The total carbohydrate content of intact walls was measured using a colorimetric tryptophan + boric acid + sulphuric acid technique (Badin, Jackson \& Schubert, 1957). This was chosen both because the reaction with carbohydrates is not sensitive to the presence of proteins and because glucose and mannose give the same colour yield in this reaction. This method is therefore far more satisfactory than the anthrone method for walls which contain mannan, glucan and protein.

Hexosamine. Hexosamine was measured using the Elson-Morgan reagents (Boas, 1953) with glucosamine standards.

Glucose-6-phosphate. This was measured as described by Horecker \& Wood (1957).

Anthrone assay. The method of Scott \& Melvin (1953) was used.

Carbohydrate determinations on whole cells. An attempt was made to apply the original technique of Trevelyan \& Harrison (1952) to flocculent and non-flocculent organisms but the variation of replicate determinations was so large that the method was not suitable. However, the revised method of determination (Trevelyan \& Harrison, 1956) yielded reproducible results.

Periodate oxidation of hexose phosphate. The solution of hexose phosphate was standardized by the estimation of its organic phosphate content and was then diluted so as to contain about $2 \mu$ mole organic $\mathbf{P} / \mathrm{ml}$. Equal volumes of this solution and of $0.02 \mathrm{M}$-sodium periodate were mixed at $4^{\circ}$ and held in the dark at this temperature. Duplicate oxidations and controls, lacking the hexose phosphate, were performed simultaneously. At intervals $1 \mathrm{ml}$. samples were withdrawn for the estimation of residual periodate (Fleury \& Lange, 1933) and, when a constant value was reached, a further $\mathbf{0 . 2} \mathbf{~ m l}$. sample was taken for determination of its formaldehyde content (Speck, 1962).

Determination of mannose-6-phosphate. An estimate of mannose-6-phosphate was 
obtained by column chromatography. A dilute solution containing the sugar was brought to $\mathrm{pH} 8.5$ with $0.1 \mathrm{~N}-\mathrm{NH}_{4} \mathrm{OH}$, and passed through a column $(80 \times 0.5 \mathrm{~cm}$. $)$ of Amberlite CG 400 resin, type II, in the chloride form. Elution was carried out using a linear gradient between $11.0 .009 \mathrm{M}-\mathrm{Na}_{2} \mathrm{~B}_{4} \mathrm{O}_{7}$ in $0.035 \mathrm{M}-\mathrm{NH}_{4} \mathrm{Cl}$ in a mixing vessel and 1 1. $0.002 \mathrm{M}-\mathrm{Na}_{2} \mathrm{~B}_{4} \mathrm{O}_{7}$ in $0.035 \mathrm{M}-\mathrm{NH}_{4} \mathrm{Cl}$ in a reservoir. Eluent was pumped to the column at a rate of $30 \mathrm{ml}$./ $\mathrm{hr}$ and $20 \mathrm{ml}$. fractions were collected.

One ml. $5 \mathrm{~N}-\mathrm{H}_{2} \mathrm{SO}_{4}$ was added to each tube and each fraction was concentrated to a low bulk at $110^{\circ}$ in an oven. Digestion was completed over an open flame and the phosphate content of the digest was determined. Control runs showed that inorganic phosphate appeared at about tube no. 15, glucose-6-phosphate at about tube no. 22 and mannose-6-phosphate at about tube no. 36. In a control run using a commercial preparation of mannose-6-phosphate, containing $71 \mu \mathrm{g}$. organic $\mathrm{P}$, a total of $69 \cdot 2 \mu \mathrm{g}$. P was obtained for the mannose-6-phosphate peak.

Paper chromatography. Chromatograms were prepared on Whatman paper no. 54 using as solvents $(a)$ pyridine + ethyl acetate + water $(5+12+4, \mathrm{v} / \mathrm{v}$.$) and (b)$ phenol + water $(4+1, w / v)$. Reducing sugars were detected with aniline oxalate; sugar phosphates were detected by the method of Hanes \& Isherwood (1949).

Paper electrophoresis. Horizontal paper electrophoresis was carried out on Whatman paper no. 54 in a $0.05 \mathrm{M}$ sodium tetraborate + boric acid buffer $\mathrm{pH} 8 \cdot 8$, for $2 \mathrm{hr}$. at $20 \mathrm{~V} . / \mathrm{cm}$. The papers were dried and the sugars were detected with alkaline silver nitrate (Trevelyan, Procter \& Harrison, 1950).

Nitrogen. The total nitrogen content of walls was assayed by digesting about $20 \mathrm{mg}$. in $2 \mathrm{ml} .5 \mathrm{~N}-\mathrm{H}_{2} \mathrm{SO}_{4}$ with $0.05 \mathrm{ml} .30 \% \mathrm{H}_{2} \mathrm{O}_{2}$ for $16 \mathrm{hr}$. The digests were cooled and diluted to $10 \mathrm{ml}$. and the ammonia was estimated as described by Conway (1957).

Phosphorus. Total phosphorus was determined by digesting about $10 \mathrm{mg}$. walls (dry weight) in $1 \mathrm{ml} .5 \mathrm{~N}-\mathrm{H}_{2} \mathrm{SO}_{4}$ and adding drops of $2 \mathrm{~N}-\mathrm{HNO}_{3}$ to complete the digestion. The digests were diluted with $1 \mathrm{ml}$. water and heated for $3 \mathrm{~min}$. at $100^{\circ}$ and then their phosphate content was determined (Fiske \& Subbarow, 1925). Inorganic $\mathbf{P}$ was determined by omitting the digestion step and removing insoluble material by centrifuging the assay mixture before adding the colour reagent.

Titration curves. Titration curves were prepared by suspending, or dissolving the material under investigation in $10 \mathrm{ml}$. $\mathrm{CO}_{2}$-free water and immersing in it the electrodes of a $\mathrm{pH}$ meter. The $\mathrm{pH}$ was first adjusted to 9.5 with a little $\mathrm{CO}_{2}$-free $\mathrm{NaOH}$ solution. The mixture was then quickly titrated with $0 \cdot 1 \mathrm{~N}-\mathrm{HCl}$ added in small increments from a micrometer syringe; after each addition the mixture was well stirred and the $\mathrm{pH}$ was noted.

\section{RESULTS}

\section{The wall preparations}

Microscopically the walls looked like empty 'shells' of yeast. No intact organisms were found and in a microscope field containing thousands of walls, only a very occasional, minute, highly refractile, foreign particle was seen. Wall preparations from both flocculent and non-flocculent organisms showed a slight tendency to aggregate when in concentrated suspensions in water. However, when transferred to buffered calcium chloride solution $\left(0.025 \mathrm{M}-\mathrm{CH}_{3} . \mathrm{COOH}, 0.025 \mathrm{M}-\mathrm{CH}_{3} . \mathrm{COONa}\right.$ 
$\mathrm{CaCl}_{2} 1 \mathrm{~g}$./l.) the walls from flocculent organisms formed large flocs, whereas those from non-flocculent organisms remained unchanged. Unless otherwise stated analyses were made on single large batches of flocculent or non-flocculent walls, each obtained by pooling four smaller batches.

\section{Carbohydrates of the walls}

A fraction of the glucan of the yeast cell wall is notoriously resistant to acid hydrolysis and conditions which were sufficiently vigorous to hydrolyse this fraction would also destroy some of the sugars formed. It was not therefore possible to carry out a completely direct hydrolysis and determination of the sugar content.

When walls were subjected to hydrolysis in $2 \mathrm{~N}-\mathrm{H}_{2} \mathrm{SO}_{4}$ at $100^{\circ}$ for $2 \mathrm{hr}$ they partly dissolved. The soluble and insoluble fractions were separated by centrifugation and the insoluble fraction was hydrolysed in $6 \mathrm{~N}-\mathrm{H}_{2} \mathrm{SO}_{4}$ at $100^{\circ}$ for $16 \mathrm{hr}$. The two hydrolysates were neutralized with excess $\mathrm{BaCO}_{3}$, the precipitate was removed, and the supernatant was concentrated under vacuum and used for paper chromatography. The $2 \mathrm{~N}-\mathrm{H}_{2} \mathrm{SO}_{4}$ hydrolysate contained both mannose and glucose; the $6 \mathrm{~N}-\mathrm{H}_{2} \mathrm{SO}_{4}$ hydrolysate contained glucose as the only detectable sugar. Samples of walls were therefore hydrolysed in $2 \mathrm{~N}-\mathrm{H}_{2} \mathrm{SO}_{4}$ as before; the insoluble residue was

Table 2. Carbohydrate composition of flocculent and non-flocculent cell walls

The carbohydrates are expressed in terms of anhydro sugars- $\mathrm{C}_{6} \mathrm{H}_{10} \mathrm{O}_{5}$.

\begin{tabular}{lcc}
\multicolumn{1}{c}{ Component } & $\overbrace{\text { Flocculent }}^{\text {\% dry weight }}$ & Non-flocculent \\
Glucose & 34 & 34 \\
Unhydrolysed & 12 & 13 \\
Hydrolysed & 46 & 47 \\
Total & 43 & 44 \\
Mannose & 89 & 91 \\
Total mannose+glucose & & \\
Total carbohydrate found in intact & 88 & 90 \\
walls & $1 \cdot 1$ & $1 \cdot 1$ \\
Glucosamine & &
\end{tabular}

separated and assayed for carbohydrate using the anthrone assay with glucose standards. The soluble portion of the hydrolysate was neutralized with $\mathrm{BaCO}_{3}$ and assayed first for glucose and secondly for reducing sugars using standards which contained the determined glucose content and different amounts of mannose. The mannose content could thus be calculated. The total carbohydrate content of unhydrolysed walls was also determined. Glucosamine was measured after hydrolysis of walls in $6 \mathrm{~N}-\mathrm{HCl}$ at $100^{\circ}$ for $16 \mathrm{hr}$. Table 2 presents all these results; the concentrations of sugars are given as \% anhydro sugar $\left(\mathrm{C}_{6} \mathrm{H}_{10} \mathrm{O}_{5}\right)$ per mg. cell wall (dry wt.). The location of glucosamine amongst the hydrolysed fractions was not determined, so that these figures may include a small contribution from this. 


\section{Carbohydrates in whole yeast}

Cultures of the yeast were harvested 18,26 and $48 \mathrm{hr}$ after inoculation. The potential flocculence of the yeast was measured (Mill, 1964) and the mannan and glucan contents were determined by the revised extraction method. Table 3 shows that there was little difference in the relative proportions of the two polysaccharides in the three samples of yeast which were potentially non-flocculent, fairly flocculent and very flocculent respectively.

Table 3. The content of mannan and glucan in yeasts of different potential flocculence

Determined by the extraction of whole cells (Trevelyan \& Harrison, 1956).

\begin{tabular}{lccc} 
& \multicolumn{3}{c}{ Yeast harvested after } \\
\cline { 2 - 4 } & $18 \mathrm{hr}$. & $26 \mathrm{hr}$. & $42 \mathrm{hr}$. \\
Mannan (\% dry weight) & $9 \cdot 6$ & $9 \cdot 9$ & $8 \cdot 5$ \\
Glucan (\% dry weight) & $5 \cdot 3$ & $6 \cdot 0$ & $5 \cdot 3$ \\
Ratio mannan/glucan & $1 \cdot 8$ & $1 \cdot 6$ & $1 \cdot 6$ \\
Potential flocculence (g./ml./min.) & 25 & 650 & 6000
\end{tabular}

Table 4. The $\boldsymbol{N}$ and $\boldsymbol{P}$ content of flocculent and non-flocculent walls

$\quad$ Component
Total N
Glucosamine $\mathrm{N}$
Protein, taken as $6 \cdot 25(\mathrm{~N}$-glucosamine $\mathrm{N})$
Organic $\mathrm{P}$
Organic phosphate as $\mathrm{PO}_{2} \mathrm{Na}$

\begin{tabular}{cc}
\multicolumn{2}{c}{$\%$ Dry weight } \\
Flocculent & Non-flocculent \\
0.88 & $\mathbf{1 . 0 8}$ \\
0.086 & $0 \cdot 095$ \\
$4 \cdot 9$ & $6 \cdot 1$ \\
0.40 & $0 \cdot 30$ \\
1.1 & $0 \cdot 82$
\end{tabular}

Nitrogen and organic phosphate in the wall

Table 4 shows the content of nitrogenous compounds and organic phosphorus in the wall. To test the validity of the nitrogen result, assays were performed upon four small batches of flocculent walls and four of non-flocculent walls which had each been prepared independently; the mean $\mathrm{N}$ content was $0.80 \%$ and $0.99 \%$ respectively for the two types of wall. The difference was statistically significant $(t=45$, $n=8, P<0.01$ ).

\section{The location of the phosphorus}

Fifty $\mathrm{mg}$. (dry wt.) of a preparation of flocculent cell walls were hydrolysed in $4 \mathrm{ml}$. $2 \mathrm{~N}-\mathrm{H}_{2} \mathrm{SO}_{4}$ at $100^{\circ}$ for $3 \mathrm{hr}$. The hydrolysate was centrifuged and the residue was washed with water. After digestion in sulphuric acid, no phosphorus could be detected in this residual fraction; however, the supernatant fraction from the hydrolysis contained $190 \mu \mathrm{g}$. phosphorus, of which $185 \mu \mathrm{g}$. were organically bound. Thus the hydrolysis in $2 \mathrm{~N}-\mathrm{H}_{2} \mathrm{SO}_{4}$ had solubilized the phosphate but had left it organically bound. 


\section{Acid stability of the phosphate bond}

Phosphate esters differ greatly in their resistance to acid hydrolysis. Since hydrolysis in $2 \mathrm{~N}$-acid for $\mathbf{3} \mathrm{hr}$ solubilized all the organic phosphate of the cell wall, some idea of the nature of this phosphate might have been obtained by measuring the rate at which inorganic phosphate was released on more prolonged hydrolysis. Accordingly, $5 \mathrm{mg}$. of a preparation of flocculent walls were suspended in $5 \mathrm{ml}$. $\mathrm{N}-\mathrm{H}_{2} \mathrm{SO}_{4}$ and heated at $100^{\circ}$ for $16 \mathrm{hr}$. The mixture was then cooled quickly and its inorganic phosphate content was measured. The original preparation contained $20 \mu \mathrm{g}$ organic phosphate of which $5 \cdot 1 \mu \mathrm{g}$. were released as inorganic phosphate after the $16 \mathrm{hr}$ hydrolysis. This would correspond to an apparent hydrolysis constant $(K=1 / t[2.303 \log a /(a-x)])$ of about $0 \cdot 3 \times 10^{-3}$. There are obvious inaccuracies in this procedure, not least in that the hydrolytic system is originally heterogeneous, but nevertheless a comparison with published hydrolysis constants (Leloir \& Cardini, 1957) is suggestive: glucose-6-phosphate $0.5 \times 10^{-3}$, mannose-6-phosphate $0 \cdot 67 \times 10^{-3}$, glucosamine-1-phosphate $75 \times 10^{-3}$, glucose-1-phosphate $200 \times 10^{-3}$. There are, of course, other types of acid-stable phosphate but the predominantly carbohydrate nature of the cell wall suggested that hexose phosphates, and particularly the 6-phosphates, should first be considered.

\section{Isolation of organic phosphate from the cell wall}

Fifty mg. flocculent walls were heated at $100^{\circ}$ for $3 \mathrm{hr}$ in $2 \mathrm{ml} .2 \mathrm{~N}-\mathrm{H}_{2} \mathrm{SO}_{4}$. A slight excess of $\mathrm{BaCO}_{3}$ was added, the precipitate was removed and washed with $1 \mathrm{ml}$. portions of water, and washings and supernatant were combined. This mixture was then treated with $0.5 \mathrm{~g}$. Zeokarb 225 cationic exchange resin in the hydrogen form. The solution was decanted and the resin was twice washed with $2 \mathrm{ml}$. water and the washings were added to the bulk of the solution. The mixture was brought to $\mathrm{pH} \mathrm{8.5}$ with $\mathrm{N}-\mathrm{NH}_{4} \mathrm{OH}$ and passed slowly through a column $(10 \times 0.8 \mathrm{~cm}$. $)$ of Deacidite $\mathbf{K}$ anionic exchange resin in the formate form. The phosphates were eluted from the column with $30 \mathrm{ml} .0 .5 \mathrm{M}-\mathrm{HCOOH}$ and the eluate was taken to dryness at $60^{\circ}$ under vacuum. The small residue was taken up in $2 \mathrm{ml}$. water. The solution contained $172 \mu \mathrm{g}$. of phosphorus of which $167 \mu \mathrm{g}$. were organically bound.

\section{Determination of glucose-6-phosphate}

Because of the ease of the technique, the solution was first assayed for glucose-6phosphate. None was found.

\section{Paper chromatography and electrophoresis}

The material obtained as above gave a single spot, which could be detected with either aniline oxalate or the phosphate reagent, after chromatography in solvents $a$ or $b$. The position of this spot corresponded to that given by a commercial sample of mannose-6-phosphate $\left(\mathbf{R}_{\text {glucose }}\right.$ solvent $a=0 \cdot 19$; solvent $\left.b=0 \cdot 25\right)$.

On paper electrophoresis the material gave a single band in the same position as that given by mannose-6-phosphate. 


\section{The action of alkaline phosphatase}

The organic phosphate obtained from $50 \mathrm{mg}$. cell wall, as described above, was dissolved in $\mathbf{0 . 2} \mathrm{ml}$. water and mixed with two volumes of a solution of alkaline phosphatase $(8 \mathrm{u} . / \mathrm{ml}$. of the British Drug Houses preparation in a solution containing $\mathrm{M}-\left(\mathrm{NH}_{4}\right)_{2} \mathrm{CO}_{3}+\mathbf{0} \cdot 1 \mathrm{M}$-alanine). Controls were prepared in a similar manner using enzyme solution which had been heated at $100^{\circ}$ for 20 min. After holding for $4 \mathrm{hr}$ at $30^{\circ}$, the enzymic mixtures were subjected to paper chromatography with solvents $a$ and $b$, and the sugars were detected with aniline oxalate. The control experiment with boiled enzyme yielded spots corresponding to mannose-6-phosphate only, whereas the mixture with active enzyme gave only faint spots in the mannose-6-phosphate position and gave new spots corresponding to mannose ( $\mathbf{R}_{\text {glucose }}$ solvent $a \mathbf{1} \cdot 14$; solvent $\left.b \mathbf{1 \cdot 2 3}\right)$.

\section{Isolation of the mannose phosphate on a larger scale}

The amount of the mannose phosphate which could be obtained from cell walls was limited and in order to obtain larger amounts for further characterization an attempt was made to separate it from whole organisms. Since the mannose phosphate presumably came from the mannan fraction of the wall, this was first separated, as described, from flocculent cells. Four hundred mg. of this material were hydrolysed in $2 \mathrm{ml} .2 \mathrm{~N}-\mathrm{HCl}$ at $100^{\circ}$ for $3 \mathrm{hr}$, and the hydrolysate was dried in a vacuum desiccator containing $\mathrm{H}_{2} \mathrm{SO}_{4}$ and solid $\mathrm{NaOH}$. The residue was dissolved in water, brought to about $\mathrm{pH} 8.2$ with $\mathrm{N}-\mathrm{KOH}$ and mixed with $0.5 \mathrm{ml}$. of a saturated solution of barium acetate. The mixture was cooled in ice for $30 \mathrm{~min}$., a small precipitate was removed, and the organic phosphate was precipitated as its barium salt by adding the solution to four volumes of ice-cold ethanol. The precipitate was dissolved in $5 \mathrm{ml}$. water, reprecipitated with four vol. ethanol, washed with ethanol and ether, and dried in a vacuum desiccator. A total of $95 \mathrm{mg}$. of the salt was obtained.

It was purified further on a column of anionic exchange resin, essentially as described for the material obtained from the cell wall. The column was eluted with $20 \mathrm{ml} .0 .05 \mathrm{~N}-\mathrm{HCl}$ and the eluate was brought to $\mathrm{pH} 3.8$ with $0.2 \mathrm{~N}-\mathrm{KOH}$ and held frozen until required. This solution contained $55 \mu \mathrm{g}$. of organic phosphorus $/ \mathrm{ml}$. It behaved exactly like the material isolated directly from the cell wall, when subjected to paper electrophoresis and chromatography and treatment with alkaline phosphatase.

\section{Periodate oxidation}

The solution of organic phosphate was subjected to periodate oxidation as described. After $5 \mathrm{~min}$., $4 \mathrm{hr}, 20 \mathrm{hr}$, and $28 \mathrm{hr}$ of reaction, each mole of organic phosphate had consumed $1.98,3.95,3.95$ and 4.08 moles of periodate respectively and finally liberated only $\mathbf{0 . 0 3}$ mole of formaldehyde. Of all possible mannose phosphates only the 6-phosphate would consume 4 moles of periodate for each mole of phosphate without liberating formaldehyde.

\section{Estimation of the mannose-6-phosphate content of flocculent and non-flocculent walls}

One hundred mg. samples of each type of wall were separately hydrolysed in $4 \mathrm{ml} .2 \mathrm{~N}-\mathrm{HCl}$ at $100^{\circ}$ for $3 \mathrm{hr}$. The insoluble material was removed, about $20 \mathrm{mg}$. 
$\mathrm{Ba}(\mathrm{OH})_{2}$ was dissolved in each hydrolysate and their $\mathrm{pH}$ was brought to $8 \cdot 2$ with $\mathrm{NH}_{4} \mathrm{OH}$. Four volumes ethanol were added and the mixtures were held at $4^{\circ}$ overnight. The precipitates were collected, washed with a little ice-cold $80 \%$ ethanol and dissolved in $10 \mathrm{ml}$. water. A trace of insoluble material was removed and then the solutions were added directly to the resin columns for the estimation of mannose6-phosphate. In each case peaks were obtained corresponding to inorganic phosphate and mannose-6-phosphate together with a small quantity of an unidentified phosphate which appeared in the first few tubes (Table 5).

Table 5. Phosphates present in hydrolysates of flocculent and non-flocculent cell walls

The table shows the phosphates recovered from cell walls after hydrolysis in $2 \mathrm{~N}-\mathrm{HCl}$ at $100^{\circ}$ for $3 \mathrm{hr}$.

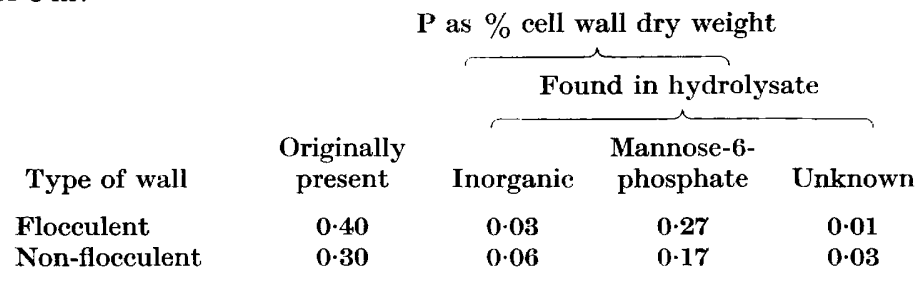

Table 6. Degree of phosphorylation of mannans from yeast cells of different levels of potential flocculence

The potential flocculence of the cell is expressed as the sedimentation rate (s.r.) (Mill, 1964). Mannose content is given as the anhydro sugar $=\mathrm{C}_{6} \mathrm{H}_{10} \mathrm{O}_{5}$.

$\begin{array}{ccccc}\begin{array}{c}\text { Period of } \\ \text { growth }(\mathrm{hr})\end{array} & \begin{array}{c}\text { s.R. of yeast } \\ (\mu \mathrm{g} . / \mathrm{ml} . / \mathrm{min})\end{array} & \begin{array}{c}\text { Mannose in } \\ \text { mannan }(\%)\end{array} & \begin{array}{c}\text { Phosphorus in } \\ \text { mannan }(\%)\end{array} & \begin{array}{c}\text { Mole ratio } \\ (\text { mannose } / \mathbf{P})\end{array} \\ 16 & 25 & 83 & 0 \cdot 80 & 19 \\ 22 & 30 & 83 & 1 \cdot 00 & 15 \\ 40 & 780 & 84 & 1 \cdot 06 & 14 \\ 64 & 2600 & 78 & 1 \cdot 09 & 13\end{array}$

Changes in the phosphorylation of the mannan during growth

Yeast was grown in GYSA medium and samples of cells were collected at intervals. Their sedimentation rate was measured (Mill, 1964), and the mannan was isolated from them and its phosphate content determined. The carbohydrate content of the mannans was measured using anthrone (Table 6).

\section{Titration curves of cell walls and mannan}

The titration curve for 50 mg. mannan (Fig. 1) showed a distinct inflexion between pH 6 and 7.5 which could be attributed to the dissociation of the second hydrogen ion of its phosphate ester groups.

However, the titration curve for $50 \mathrm{mg}$. flocculent cell walls (Fig. 2a) showed no such inflexion. This suggested that the phosphate was present in the wall as a diester. Accordingly, $50 \mathrm{mg}$. of the flocculent walls were heated to $100^{\circ}$ in $2 \mathrm{ml}$. $\mathrm{N}-\mathrm{HCl}$ for 15 min., and a titration curve was prepared for the whole mixture (Fig. 2b). A distinct inflexion was now found. By subtracting the titre for the 
unhydrolysed walls at each $\mathrm{pH}$ from the titre for the hydrolysed walls, and then plotting the corresponding $\mathrm{pH}$ values against the differences in titres, it was possible to construct a titration curve for the groups released on hydrolysis. Figure 3 shows points representing values obtained in this way. However, the solid curve shown was obtained by calculating titration values for a hypothetical group having a $\mathrm{p} K$ of 6.2 and present in the concentration at which phosphate groups were present in the wall, i.e. $6 \cdot 45 \mu$-equiv. in the $50 \mathrm{mg}$. sample. Thus, in the $\mathrm{pH}$ range at which the second hydrogen ion of an organic phosphate would ionize, the difference between the titration curves of hydrolysed and unhydrolysed walls could be accounted for by the ionization of a group in the hydrolysed wall having the $\mathrm{p} K$ and the concentration of the phosphate.

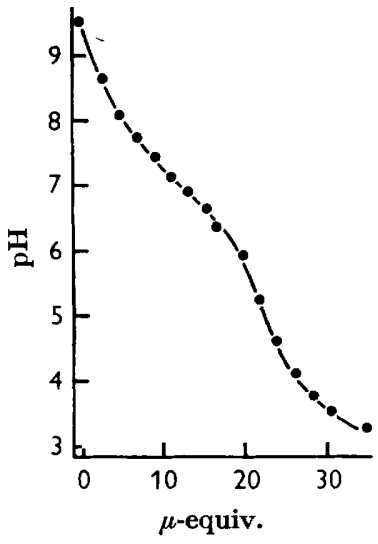

Fig. 1

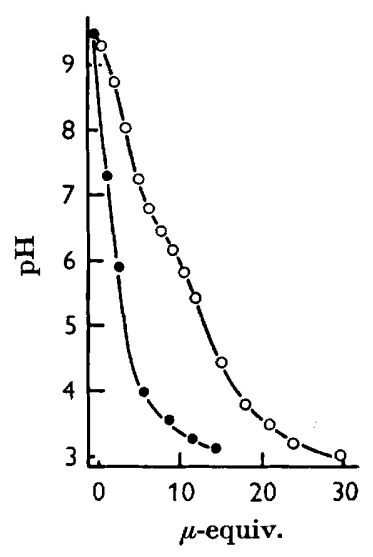

Fig. 2

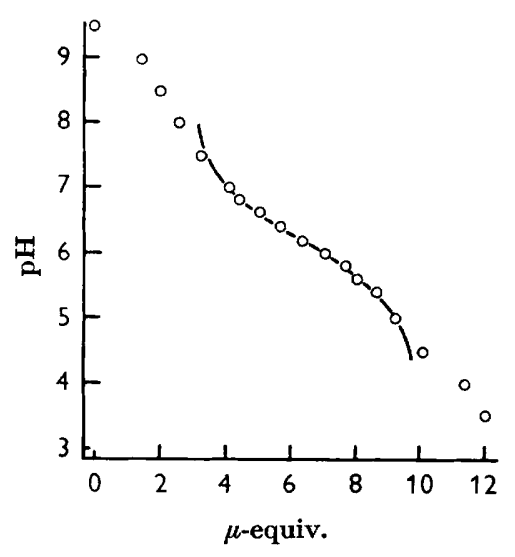

Fig. 3

Fig. 1. Titration curve for $50 \mathrm{mg}$. mannan isolated from flocculent yeast. The sample was brought to $\mathrm{pH} 9.5$ with $\mathrm{NaOH}$ and then titrated with $0.1 \mathrm{~N}-\mathrm{HCl}$.

Fig. 2. Titration curves for (O); $50 \mathrm{mg}$. flocculent cell walls,; (O) $50 \mathrm{mg}$. flocculent cell walls hydrolysed in $\mathrm{N}-\mathrm{HCl}$ for $15 \mathrm{~min}$. at $100^{\circ}$. Both samples were adjusted to $\mathrm{pH} \mathrm{9.5}$ with $\mathrm{NaOH}$ and then titrated with $0 \cdot 1 \mathrm{~N}-\mathrm{HCl}$.

Fig. 3. Difference in the titration curves for hydrolysed and non-hydrolysed yeast. The points $(O)$ represent differences in titres, at each $\mathrm{pH}$ value, of the two curves shown in Fig. 2. The solid line is a calculated curve for the titration of $6 \cdot 45 \mu$-equiv. of a group of pK 6.2; this curve is positioned to coincide with the experimental points at $\mathrm{pH} 6 \cdot 2$.

Strictly analogous curves were obtained for non-flocculent walls. In this case the difference before and after hydrolysis could be accounted for by the ionization of a group in the non-flocculent wall having a $\mathrm{p} K$ of $6 \cdot 2$ and a concentration of $4 \cdot 8 \mu$ equiv. in the $50 \mathrm{mg}$. sample. Even milder hydrolytic conditions sufficed to release the secondary phosphate groups. Fifty $\mathrm{mg}$. flocculent walls, hydrolysed in $\mathbf{0} \cdot 1 \mathrm{~N}-\mathrm{HCl}$ for $5 \mathrm{~min}$. at $100^{\circ}$ showed an inflexion, with a $\mathrm{pK}$ of about $6 \cdot 2$, amounting to $4.7 \mu$-equiv., i.e. $73 \%$ of the secondary phosphate groups of the walls were liberated by this mild hydrolysis.

\section{DISCUSSION}

About 95-98\% of the dry weight of these wall preparations is accounted for by the analyses as carbohydrate, phosphate or protein, but it is possible that lipoidal material, including phospholipid, was removed during the preparation of the walls. 
The carbohydrate content of the walls was somewhat higher than has been previously reported, but the agreement between the estimated total carbohydrate content and the sum of the individual fractions argues for the validity of the method. The ratio of mannose to glucose was $0.94 / 1$ for both flocculent and non-flocculent walls. Northcote \& Horne (1952) and Roelofson (1953) had found ratios of about 1/1, but Masschelein (1959) and Masschelein et al. (1963) reported changes in the mannan content of Saccharomyces carlsbergensis, so that the mannan/glucan ratio varied between $1 \cdot 6 / 1$ and $5 \cdot 3 / 1$. They suggested that the flocculence state of the cell was in fact dependent upon its mannan content. This mechanism does not appear to operate in the strain of $\boldsymbol{S}$. cerevisiae used in the present study. Direct determinations of mannan and glucan on whole cells gave a higher ratio of mannan to glucan but once again there was little difference between cells of widely different flocculence.

The higher nitrogen content of the non-flocculent walls is of interest in relation to the observation (Mill, 1964) that certain nitrogenous compounds, when added to the medium, delayed the onset of flocculation in cultures of this yeast.

Northcote \& Horne (1952) reported that a mannan isolated from cell walls of bakers' yeast contained $0 \cdot 3 \% \mathbf{P}$ whereas the glucan fraction of the walls contained only $0.008 \%$. Falcone \& Nickerson (1956) found that isolated cell walls of bakers' yeast contained $0 \cdot 34 \% \mathbf{P}$. Eddy (1958) detected a maximum of $1 \% \mathbf{P}$ in a mannanprotein complex from walls of brewers' yeast. Two fractions isolated from cell walls by Korn \& Northcote (1960) contained mannose, phosphorus and nitrogen. Thus although it was clear that the mannan and phosphorus were in some way associated it was not known whether the mannan itself was phosphorylated, or was complexed with a phosphoprotein. Moreover Haworth, Heath \& Peat (1941) and Peat, Turvey $\&$ Doyle (1961) did not report the presence of phosphorus in mannan which they isolated from baker's yeast.

The flocculent walls isolated in the present investigation contained more phosphorus than the non-flocculent ones, and these experiments established that most, at least, of the phosphorus was present as an ester of hydroxyl groups in position 6 of residues in the mannan. The identification of mannose-6-phosphate in hydrolysates, both of cell walls and isolated mannan, rests upon the behaviour of the phosphate on paper electrophoresis, paper and ion-exchange chromatography, its hydrolysis to mannose by alkaline phosphatase, and the results of the periodate estimation. In the quantitative estimation of mannose-6-phosphate released on hydrolysis of the walls, not much more than $75 \%$ of the total phosphate of the walls was detected. This may mean that another, undetected phosphate was present, but it probably reflected losses in the hydrolysis and isolation of the relatively small amounts of mannose-6-phosphate present in the walls. The difference in the amounts of mannose-6-phosphate recovered from flocculent and non-flocculent walls was of the right order to account for the difference in the total phosphorus contents of the two types of walls.

The separation of the phosphate attached to the extracted mannan fraction of the wall presumably means that the mannose residue of the mannose-6-phosphate formed a part of the mannan. If the structure which Peat et al. (1961) proposed for Sacharomyces cerevisiae mannan is accepted, then the backbone residues are 1,6 linked so that the phosphate groups must be attached to residues in the side chain of the mannan molecule. 
The hypothesis that the difference in the phosphorus content of flocculent and non-flocculent cell walls is due to the difference in the content of mannose-6phosphate residues is supported by the finding that the mannan isolated from more flocculent cells was more highly phosphorylated. However, there is as yet no evidence that the relationship is causal; the less flocculent cells are also the more rapidly growing cells and it is not impossible that the presence of phosphate groups on the mannan is concerned with growth.

The study of the titration curves in Figs. 2 and 3 shows that the phosphate in the native cell wall is in fact diesterified. A monoester of phosphoric acid will give a titration curve with two points of inflexion-at about $\mathrm{pH} \mathrm{1-2}$ and $\mathrm{pH}$ 6-7. The second of these inflexions will be lost if the phosphate is diesterified. The titration curve for mannan clearly showed this second inflexion, indicating that monoesterified phosphate was present in the isolated mannan. However, the curves for both flocculent and non-flocculent walls showed no trace of the second inflexion unless they were first subjected to a brief acid hydrolysis. Following hydrolysis in $\mathrm{N}-\mathrm{HCl}$ at $100^{\circ}$, all the phosphate of the wall was present as the monoester. Clearly the phosphate in the native wall is diesterified but the second bond is very labile.

What has been discovered of the structure which contains the phosphate is very reminiscent of the phosphomannan released exocellularly by Hansenula holstii and H. capsulata (Jeanes, Pittsley, Watson \& Dimler, 1961; Slodki, 1962). These exocellular phosphomannans also contained diesterified phosphate. One of the ester bonds involved the 6 position of a mannose residue and the other formed a hemiacetal bond with the 1 position of another mannose residue. This latter bond was very labile to acids. The $H$. holstii mannan had a mannose/phosphorus ratio of 5 and the $\boldsymbol{H}$. capsulata mannan a ratio of $\mathbf{2 \cdot 5}$. These are much lower ratios than those found for the structural mannan of the wall of Saccharomyces cerevisiae but the possibility that the two compounds are homologous must be borne in mind.

The author wishes to thank Miles Laboratories Ltd. for assistance in the completion of this work which was initiated elsewhere.

\section{REFERENCES}

BoAs, N. F. (1953). Method for the determination of hexosamines in tissues. J. biol. chem. 204, 553.

Badin, J., Jackson, C. \& Schubert, M. (1957). Improved method for determination of plasma polysaccharides with tryptophan. Proc. Soc. exp. Biol. Med. 84, 288.

Conway, E. G. (1957). Microdiffusion Analysis and Volumetric Error. London: Lockwood and Son Ltd.

EDDy, A. A. (1958). The structure of the yeast cell wall. II. Degradative studies with enzymes. Proc. roy. Soc. B 149, 425.

Falcone, G. \& Nickerson, W. J. (1956). Cell-wall mannan-protein of baker's yeast. Science 124, 272.

Fiske, C. H. \& Subbarow, Y. (1925). The colorimetric determination of phosphorus. J. biol. Chem. 66, 375.

Fleury, P. F. \& LANGe, J. (1933). Determination of periodic acid in the presence of iodic acid. J. Pharm. Chim., Paris 17, 107.

Hanes, C. S Isherwood, \& F. A. (1949). Separation of the phosphoric esters on the filter paper chromatogram, Nature, Lond. 164, 1107.

Haworth, W. N., Heath, R. L. \& Peat, S. (1941). Constitution of yeast mannan. J. chem. Soc. p. 833. 
Haworth, W. N., Hirst, E. L. \& Isherwood, F. A. (1937). Polysaccharides. XXIV. Yeast mannan. J. chem. Soc. p. 784.

Horecker, B. L. \& Wood, W. A. (1957). D-glucose-6-phosphate. Meth. Enzym. 3, 153.

Jeanes, A., Prttsley, J. E., Watson, P. R. \& Dimler, R. J. (1961). Characterization and properties of the phosphomannan from Hansenula holstii NRRL-Y-2448. Arch. Biochem. Biophys. 92, 343.

Kaplan, O. N. (1957). Enzymatic determination of free sugars. Meth. Enzym. 3, 107.

Korn, E. D. \& Northcote, H. (1960). Physical and chemical properties of polysaccharides and glycoproteins of the yeast cell wall. Biochem. J. 75, 12.

Leloir, L. F. \& CARdini, C. E. (1957). Characterization of phosphorus compounds by acid lability. Meth. Enzym. 3, 840.

Masschelein, C. A. (1959). Structure de la paroi cellulaire et mécanisme de la flocculence des levures bases. Revue-Ferment. Ind. aliment. 14, 59.

Masschelein, C. A. \& Devreux, A. (1957). Flocculence et structure de la paroi cellulaire de la levure. Proc. Eur. Brez. Conv. p. 194.

Masschelein, C. A., Jeunehomme-Ramos, C., Castiau, C. \& Devreux, A. (1963). Mechanism of phenotypic variations in the flocculence character of yeast. J. Inst. Brew. 69,332 .

MiLL, P. J. (1964). The effect of nitrogenous substances on the time of flocculation of Saccharomyces cerevisiae. J. gen. Microbiol. 35, 53.

Nelson, N. (1944). Photometric adaptation of the Somogyi method for the determination of glucose. J. biol. Chem. 153, 375 .

Northcote, D. H. \& Horse, R. W. (1952). The chemical composition and structure of the yeast cell wall. Biochem. J. 51, 232.

Peat, S., Turvey, J. R. \& Doyle, D. (1961). The polysaccharides of bakers' yeast. V. A further study of the mannan. J. chem. Soc. p. 3918.

Roelofsen, P. A. (1953). Yeast mannan, a cell wall constituent of bakers' yeast. Biochim. Biophys. Acta 10, 477 .

Scotr, T. A. \& Melvin, E. H. (1953). Determination of dextran with anthrone. Anal. chem. 25, 1656.

Slodkr, M. E. (1962). Phosphate linkages in phosphomannans from yeast. Biochim. biophys. Acta 57, 525.

SpEck, J. C. (1962). Determination of formaldehyde. Meth. carbohyd. Chem. 1, 441.

Trevelyan, W. E. \& Harrison, J. S. (1952). Yeast metabolism. 1. Fractionation and microdetermination of cell carbohydrates. Biochem. J. 50, 298.

Trevelyan, W. E. \& Harrison, J.S. (1956). Yeast metabolism. 7. Yeast carbohydrate fractions, separation from nucleic acid, analysis, and behaviour during fermentation. Biochem. J. 63, 23.

Trevelyan, W. E., Procter, D. P. \& Harrison, J. S. (1950). Detection of sugars on paper chromatograms. Nature, Lond. 166, 444 